\title{
Alfred Russel Wallace
}

\section{Archipelag Malajski: kraina orangutana i rajskiego ptaka. Opowieść o podróży, ze studiami człowieka i natury ${ }^{*}$}

\section{Borneo - Orangutan}

Jednym z głównych celów mojego przyjazdu do Simunjon ${ }^{1}$ było zobaczenie Orangutana $^{2}$ (albo wielkiej małpy człekokształtnej z Borneo) w naturalnym środowisku, zbadanie jego zwyczajów, zdobycie dobrych okazów różnych odmian i gatunków obojga płci, dorosłych i młodych zwierząt. Wszystkie te cele zrealizowałem ponad wszelkie oczekiwania. Zdam teraz relację z mojego doświadczenia polowania na Orangutana albo „Miasa”, jak go nazywają miejscowi; jako że jest to nazwa krótka i łatwa w wymowie, będę jej zwykle używać zamiast Simia satyrus ${ }^{3}$ lub Orangutan.

Zaledwie tydzień po moim przybyciu do kopalni ${ }^{4}$ zobaczyłem Miasa po raz pierwszy. Wyszedłem zbierać owady, nie dalej niż ćwierć mili ${ }^{5}$ od domu, kiedy usłyszałem na pobliskim drzewie szelest i, spojrzawszy w górę, zobaczyłem

* Podstawa przekładu: A.R. Wallace, The Malay Archipelago: The Land of the Orang-Utan, and the Bird of Paradise. A Narrative of Travel, with Studies of Man and Nature, London 1869. Przekład obejmuje rozdz. 4. Borneo - Orangutan (s. 61-89) oraz rozdz. 17. Celebes - Menado (s. 396-404) z t. 1; http://darwin-online.org.uk/converted/Ancillary/1869_MalayArchipelago_ A1013.1/1869_MalayArchipelago_A1013.1.1.html_(dostęp: 16.08.2019).

${ }^{1}$ Właściwie Simunjan - małe miasteczko i region o tej samej nazwie w północno-zachodniej części Borneo (wszyskie przypisy są autorstwa tłumacza, chyba że oznaczono je jako A.R.W. Alfred Russel Wallace).

${ }^{2}$ Zgodnie z przyjętą przez A.R. Wallace'a konwencją w przekładzie nazwy Orangutan, Orang i Mias będą pisane dużą literą. W języku malajskim Orang hutan oznacza bowiem 'człowieka lasu'.

${ }^{3}$ Łac. simia - małpa człekokształtna, satyrus - satyr, faun.

${ }^{4}$ Kopalnie węgla w Simunjan.

51 mila $=1609,31$ metra. 
wielkie rudowłose zwierzę, poruszające się wolno, zwisające z gałęzi na rękach. Przenosił się z drzewa na drzewo, aż zniknął w dżungli, która była tak bagnista, że nie mogłem za nim podążyć. Ten sposób przemieszczania się był jednak nader niezwykły - jest on bardziej charakterystyczny dla Hylobates ${ }^{6}$ niż dla Oranga. Przypuszczam, że była to jakaś jednostkowa osobliwość tego zwierzęcia albo że z powodu specyfiki drzew rosnących w tym właśnie miejscu ten sposób był dla niego najłatwiejszy.

Około dwóch tygodni później usłyszałem, że jeden żeruje na drzewie na bagnie tuż pod domem. Wziąłem broń i miałem na tyle szczęścia, że tam właśnie go znalazłem. Skoro tylko się zbliżyłem, próbował ukryć się w listowiu, ale oddałem do niego jeden strzał, a po strzale z drugiej lufy upadł prawie martwy, z dwoma kulami w ciele. Był to samiec, mniej więcej na wpół wyrośnięty, wysoki na niecałe trzy stopy. 26 kwietnia, kiedy byłem z dwoma Dajakami ${ }^{7}$ na polowaniu, znaleźliśmy kolejnego, podobnych rozmiarów. Spadł po pierwszym strzale, ale nie wydawał się zbytnio zraniony i natychmiast wspiął się na najbliższe drzewo, a ja strzeliłem i znowu spadł, ze złamanym ramieniem i raną w korpusie. Dwaj Dajakowie natychmiast do niego podbiegli i każdy uchwycił jedną rękę, mówiąc mi, żebym ściął żerdź, a oni go przymocują. Ale chociaż jedno ramię miał złamane i był zwierzęciem jedynie w połowie wyrośniętym, był zbyt silny dla tych młodych dzikusów. Pomimo całego ich wysiłku przyciągał ich do swego pyska, aż musieli ponownie go wypuścić, bo zostaliby dotkliwie pogryzieni. Natychmiast znowu zaczął wspinać się na drzewo, więc żeby uniknąć problemów, strzeliłem mu w serce.

2 maja, mając $\mathrm{z}$ sobą tylko mały karabin kalibru osiemdziesiąt, znowu znalazłem jednego na bardzo wysokim drzewie. Wystrzeliłem jednak, a on, zauważywszy mnie, zaczął ryczeć dziwnym głosem, jakby kaszląc, odłamywać rękoma gałęzie i rzucać je w dół, a potem szybko umknął ponad wierzchołki drzew. Nie miałem ochoty go gonić, bo teren był bagienny, miejscami niebezpieczny i w zapale pościgu $\mathrm{z}$ łatwością mógłbym się zgubić.

12 maja znalazłem następnego, który zachowywał się w podobny sposób, rycząc i hukając $\mathrm{z}$ wściekłością oraz rzucając $\mathrm{w}$ dół gałęzie. Strzeliłem do niego pięć razy. Pozostał martwy na wierzchołku drzewa, wsparty na rozgałęzieniu w taki sposób, że z całą pewnością nie spadłby. Udałem się więc z powrotem do domu i szczęśliwie znalazłem kilku Dajaków, którzy wrócili ze mną i wspięli się po zwierzę. Był to pierwszy w pełni dorosły okaz, jakiego zdobyłem, ale samica, nawet nie w połowie tak wielka czy godna uwagi jak w pełni wyrośnięte samce. Miała jednak trzy stopy ${ }^{8}$ i sześć cali ${ }^{9}$ wzrostu, a jej ramiona rozciągały się na sze-

\footnotetext{
${ }^{6}$ Rodzaj małp człekokształtnych z rodziny gibonowatych.

${ }^{7}$ Dajakowie - rdzenne ludy Borneo.

81 stopa $=30,48$ centymetra.

$91 \mathrm{cal}=2,54$ centymetra.
} 
rokość sześciu stóp i sześciu cali. Zakonserwowałem skórę tego okazu w beczce araku i wypreparowałem doskonały szkielet, który został później zakupiony dla Derby Museum.

Zaledwie cztery dni później jacyś Dajakowie zobaczyli w pobliżu tego samego miejsca kolejnego Miasa i przyszli mi o tym powiedzieć. Stwierdziliśmy, że jest to dość duży okaz, na szczycie wysokiego drzewa. Po drugim strzale spadł, obracając się, ale prawie natychmiast znowu wstał i zaczął się wspinać. Po trzecim strzale padł martwy. To także była w pełni wyrośnięta samica. Kiedy przygotowywaliśmy się, aby ją zanieść do domu, znaleźliśmy młode z twarzą w błocie. To małe stworzenie miało zaledwie około stopy długości i najwyraźniej trzymało się matki, kiedy spadła po raz pierwszy. Na szczęście wyglądało, że nie jest ranne, a kiedy oczyściliśmy mu usta z błota, zaczęło krzyczeć i wydawało się całkiem silne i żwawe. Kiedy niosłem je do domu, wsadziło mi w brodę łapy i uchwyciło się tak mocno, że z trudem się wyswobodziłem, ponieważ jego palce nawykowo zakrzywiają się na ostatnim stawie do środka, tworząc pełne haki. Nie miało wówczas ani jednego zęba, ale kilka dni później wyrżnęły mu się dwa dolne przednie. Niestety nie miałem dla niego mleka, ponieważ ani malajscy Chińczycy, ani Dajakowie nigdy tego artykułu nie używają, i na próżno pytałem o jakieś zwierzę, które mogłoby piersią karmić moje małe niemowlę. Zmuszony byłem dawać mu zupę ryżową z butelki z dutką w korku, którą po kilku próbach nauczyło się ssać, jak należy. Była to bardzo skromna dieta i małe stworzenie dobrze się na niej nie rozwijało, chociaż od czasu do czasu dodawałem cukier i mleko kokosowe, żeby była bardziej pożywna. Kiedy wkładałem mu w usta palec, ssało go z wielką siłą, wciągając policzki z całej mocy w daremnym wysiłku wydobycia odrobiny mleka i dopiero po dłuższych staraniach z oburzeniem rezygnowało i zaczynało krzyczeć całkiem jak dziecko w podobnych sytuacjach.

Kiedy się nim zajmowano lub je tulono, było bardzo ciche i pogodne, ale kiedy było odkładane, zawsze płakało; przez kilka pierwszych nocy było bardzo niespokojne i głośne. Zaadaptowałem małą skrzyneczkę na kołyskę, wyścieloną miękką matą, która codziennie była zmieniana i prana; wkrótce stwierdziłem, że konieczne jest też mycie małego Miasa. Po paru razach polubiło tę operację i gdy tylko było brudne, zaczynało płakać, i nie przestawało, dopóki go nie wziąłem i nie zaniosłem do spustu wody. Wtedy zaraz cichło, chociaż trochę się wzdrygało przy pierwszej fali zimnej wody, i robiło śmiesznie krzywe miny, gdy strumień przelewał mu się po głowie. Niewiarygodną przyjemność sprawiało mu przecieranie i wycieranie do sucha. A kiedy szczotkowałem mu włosy, wydawało się osiągać pełnię szczęścia. Leżało całkiem bez ruchu, z wyciągniętymi ramionami i nogami, podczas gdy ja dokładnie czesałem długie włosy na jego plecach i ramionach. Przez pierwszych kilka dni rozpaczliwie, kurczowo trzymało się czterema łapami wszystkiego, co mogło uchwycić. Musiałem uważać i trzymać brodę z dala, bo jego palce wczepiały się we włosy silniej niż cokolwiek innego, i nie byłem w stanie uwolnić się bez pomocy. Kiedy było niespokojne, rzucało się z łapami w gó- 
rze, próbując znaleźć coś, co mogłoby chwycić, a kiedy dostało w swoje dwie albo trzy łapy kawałek patyka lub szmaty, robiło wrażenie bardzo szczęśliwego. $\mathrm{Z}$ braku czegoś innego często chwytało się za własne stopy, a po jakimś czasie zaczęło stale krzyżować ramiona i ściskać łapami długie włosy, które rosły tuż pod przeciwnym barkiem. Wielka siła jego uścisku wkrótce osłabła i byłem zmuszony wymyślić jakiś sposób, żeby ćwiczyło i wzmacniało kończyny. Zrobiłem w tym celu krótką drabinę z trzema czy czterema szczeblami, na którą wsadzałem je, jednorazowo na kwadrans, żeby sobie powisiało. Na początku wydawało się bardzo zadowolone, ale nie mogło ułożyć wszystkich czterech łap w wygodnej pozycji, więc po kilku zmianach zwalniało uchwyt jednej łapy po drugiej i spadało na podłogę. Czasami, wisząc jedynie na dwóch łapach, jedną zwalniało i wyciągając ją do przeciwnego barku, chwytało się za włosy. Jako że wydawały mu się one dużo przyjemniejsze niż patyk, zwalniało też drugą i zwalając się, krzyżowało obie i z pełnym zadowoleniem leżało na plecach. Po tych licznych upadkach nigdy nie okazywało cierpienia. Widząc, jak bardzo lubi włosy, spróbowałem zrobić mu sztuczną matkę, zwijając w kłębek kawałek skóry bawoła i wieszając ją na wysokości około stopy nad podłogą. Na początku wydawało się, że mu to nad podziw odpowiada, bo mogło rozkładać nogi i zawsze znaleźć jakieś włosy, które ściskało $\mathrm{z}$ wielką siłą. Miałem wtedy nadzieję, że uszczęśliwiłem tę małą sierotkę; i tak się wydawało, dopóki nie zaczęło sobie przypominać utraconej rodzicielki i próbować ssać. Podciągało się do skóry i próbowało każdego możliwego miejsca, ale jako że udawało mu się łapać jedynie kępy włosów i wełny, było wielce rozgoryczone i krzyczało gwałtownie, a po dwóch lub trzech próbach całkiem odpuszczało. Pewnego dnia wełna dostała mu się do gardła i myślałem, że się udławi. Po dłuższym łapaniu tchu doszło do siebie, a ja musiałem rozebrać imitację matki na kawałki i zrezygnować z ostatniej próby ćwiczenia tego małego stworzenia.

Po pierwszym tygodniu zauważyłem, że lepiej mi się je karmi łyżką i mogę mu dawać trochę bardziej zróżnicowane i bardziej stałe jedzenie. Dobrze namoczony suchar wymieszany z odrobiną jajka i cukru, a czasami słodkimi ziemniakami, był zjadany ochoczo; a obserwowanie osobliwych zmian miny, którą wyrażało aprobatę lub niechęć do tego, co dostawało, było niezawodną rozrywką. Małe biedactwo, kiedy dostawało kęs szczególnie mu odpowiadający, lizało wargi, wciągało policzki i wznosiło oczy z wyrazem najwyższego zadowolenia. Natomiast kiedy jedzenie nie było wystarczająco słodkie lub smaczne, przez chwilę obracało kęs językiem, jakby próbując wywnioskować, jaki ma smak, a potem wypychało wszystko między wargami. Jeśli ponownie dostawało to samo jedzenie, zaczynało gwałtownie krzyczeć i kopać, dokładnie jak niemowlę w przystępie gniewu.

Miałem małego Miasa od około trzech tygodni, kiedy szczęśliwie zdobyłem młodego makaka z zajęcza wargą ${ }^{10}$ (Macacus cynomolgus), który, choć mały, był bardzo żywy i potrafił jeść sam. Umieściłem go z Miasem w tej samej skrzynce

${ }^{10}$ Makak długoogoniasty, Macaca fascicularis. 
i natychmiast zostali świetnymi przyjaciółmi, nie okazując jeden przed drugim lęku. Mała małpka siadała tej drugiej na brzuchu albo nawet na twarzy, w ogóle nie dbając o jego odczucia. Kiedy karmiłem Miasa, małpa siedziała obok, zbierając wszystko, co spadło, a czasami wyciągając łapy, aby przechwycić łyżkę. Gdy tylko kończyłem, zbierała to, co pozostało przyklejone do jego warg, a potem otwierała mu usta i sprawdzała, czy coś jeszcze ma w środku. Po wszystkim kładła się na brzuchu tego biednego stworzenia, jak na jakiejś wygodnej poduszce. Mały bezradny Mias poddawał się tym wszystkim zniewagom z najbardziej przykładną cierpliwością, niezmiernie zadowolony, że ma obok siebie coś ciepłego, co mógł z czułością wziąć w ramiona. Czasami jednak mścił się, bo kiedy małpa chciała odejść, Mias trzymał ją, jak długo się dało, za luźną skórę na plecach lub głowie i dopiero po licznych energicznych podskokach udawało jej się uciec.

Ciekawe było obserwowanie różnic w zachowaniu tych dwóch zwierząt, które musiały być w podobnym wieku. Mias, leżący całkiem bezradnie na plecach, jak bardzo małe niemowlę, przewracający się leniwie $\mathrm{z}$ boku na bok, wyciągał $\mathrm{w}$ górę wszystkie cztery łapy, chcąc coś chwycić, ale nie był w stanie naprowadzić palców na jakikolwiek określony obiekt; a kiedy był niezadowolony, otwierał prawie bezzębne usta i wyrażał swe potrzeby niemal niemowlęcym krzykiem. Natomiast mała małpka była w nieustannym ruchu, biegała i skakała, gdziekolwiek zechciała. Badała wszystko dookoła, $\mathrm{z}$ wielką precyzją chwytając najmniejsze przedmioty, kołysała się na brzegu skrzynki albo wskakiwała na słupek, częstowała się wszystkim, co nadawało się do zjedzenia i znalazło się na jej drodze. Nie mogło być większego przeciwieństwa, mały Mias w porównaniu z nią wydawał się jeszcze bardziej niemowlęcy.

Miałem go od około miesiąca, kiedy pojawiły się pewne oznaki, że uczy się chodzić samodzielnie. Położony na podłodze odpychał się nogami do przodu albo się toczył i w ten sposób niezdarnie przemieszczał. Leżąc w skrzynce, unosił się do jej krawędzi, prawie do wyprostowanej pozycji, a raz czy dwa udało mu się z niej wygramolić. Kiedy pozostawał brudny lub głodny albo jakoś inaczej zaniedbany, dopóki się nim nie zajęto, krzyczał gwałtownie, wydając na przemian pewnego rodzaju kaszlący lub pulsujący dźwięk, bardzo podobnie do dorosłego zwierzęcia. Jeśli nikogo nie było w domu albo nie zwracano na jego krzyki uwagi, po krótkiej chwili cichł, ale kiedy tylko usłyszał kroki, zaczynał wrzeszczeć znowu $-\mathrm{z}$ jeszcze większą mocą.

Po pięciu tygodniach wyrżnęły mu się dwa górne przednie zęby, ale przez cały ten czas ani trochę nie urósł, pozostając tych samych rozmiarów i wagi jak wtedy, gdy go zdobyłem. Bez wątpienia było to spowodowane brakiem mleka albo innego równie pożywnego pokarmu. Zupa ryżowa, ryż i suchary były jedynie jego kiepskim substytutem, a wytłoczone z orzecha kokosowego mleko, które mu czasami dawałem, nie całkiem służyło jego żołądkowi. Temu właśnie przypisywałem atak biegunki, na której skutek biedne stworzonko wielce cierpiało. Na szczęście mała dawka oleju rycynowego dobrze podziałała i je wyleczyła. Tydzień lub dwa 
później znowu zachorowało, tym razem poważniej. Objawom typowym dla gorączki napadowej towarzyszyły wodniste obrzęki na stopach i głowie. Całkiem straciło apetyt na jedzenie i jeszcze przez tydzień trzymało się w stanie godnym pożałowania, aż w końcu zmarło. Miałem je przez prawie trzy miesiące. Bardzo żałowałem straty mojego małego pupilka. Pragnąłem go wychowywać aż do wieku dojrzałego i zabrać do domu w Anglii. Przez kilka miesięcy dostarczał mi codziennej rozrywki swoim osobliwym zachowaniem i niezwykle śmiesznym wyrazem małego oblicza. Jego waga wynosiła trzy funty ${ }^{11} \mathrm{i}$ dziewięć uncji ${ }^{12}$, wzrost czternaście cali, a rozpiętość ramion dwadzieścia trzy cale. Zakonserwowałem jego skórę i szkielet, a robiąc to, odkryłem, że kiedy spadł z drzewa, musiał złamać ramię i nogę. Tak szybko jednak się zrosły, że na kończynach dostrzegłem jedynie twarde zgrubienia w miejscach, gdzie nastąpiło nierówne połączenie kości.

Dokładnie tydzień po złapaniu tego interesującego zwierzątka udało mi się ustrzelić w pełni wyrośniętego samca Orangutana. Właśnie wróciłem do domu z wycieczki entomologicznej, kiedy wpadł Charles ${ }^{13}$, bez tchu z powodu biegu i emocji, i wykrzyczał, z trudem łapiąc oddech: „Panie, weźmijcie broń - pośpieszcie się — taki wielki Mias!”. „Gdzie on jest?” — zapytałem, chwytając broń, która szczęśliwym trafem jedną z luf miała załadowaną. „Blisko, Panie na ścieżce do kopalni - nie może uciec". Przypadkiem dwóch Dajaków było $\mathrm{w}$ tym czasie w domu, więc ich zawołałem, aby mi towarzyszyli, i wyruszyłem, każąc Charleyowi przynieść jak najszybciej całą amunicję. Ścieżka od naszej wycinki do kopalni wiodła zboczem wzgórza, trochę w górę jego stoku, a równolegle do niej, u podnóża, zrobiono szeroki wyrąb pod drogę, w którym pracowało kilku Chińczyków. Zwierzę nie mogło więc uciec do bagnistego lasu poniżej bez schodzenia, aby przeciąć drogę, albo bez wspinania się, aby obejść wycinki. Szliśmy ostrożnie, nie czyniąc najmniejszego hałasu, nasłuchując uważnie jakichkolwiek dźwięków, które mogłyby zdradzić obecność Miasa, zatrzymując się tu i ówdzie, aby spojrzeć w górę.

Wkrótce Charley dołączył do nas w miejscu, w którym widział to stworzenie. Po wzięciu amunicji i załadowaniu drugiej lufy trochę się rozproszyliśmy, czując, że musi być gdzieś w pobliżu, bo prawdopodobnie zszedł ze wzgórza i raczej nie będzie wracał. Po krótkiej chwili usłyszałem nad głową bardzo delikatny szelest, ale patrząc w górę, niczego nie widziałem. Chodziłem we wszystkie strony, aby wejrzeć w każdą część drzewa, pod którym stałem, gdy usłyszałem ten sam dźwięk, ale głośniejszy, i dostrzegłem drżenie liści, jakby spowodowane ruchem jakiegoś ciężkiego zwierzęcia, które przemieściło się na przyległe drzewo. Natychmiast ich wszystkich przywołałem, aby podeszli i spróbowali się rozejrzeć, żebym miał możliwość oddania strzału. Nie była to łatwa sprawa, ponieważ Mias

\footnotetext{
111 funt $=453,60$ grama.

121 uncja $=28,35$ grama.

13 Charles Allen, szesnastoletni angielski chłopak, towarzyszył mi jako asystent - A.R.W.
} 
miał dar znajdowania miejsc nad gęstym listowiem. Zaraz jednak jeden z Dajaków zawołał mnie i wskazał w górę. Przyglądając się, zauważyłem wielkie, rude, włochate ciało z olbrzymią, czarną twarzą patrzącą z dużej wysokości, jakby chcąc się dowiedzieć, co tam na dole robi takie zamieszanie. Bezzwłocznie wypaliłem, a on natychmiast uciekł, więc nie byłem w stanie powiedzieć, czy go trafiłem. Jak na tak duże zwierzę poruszał się teraz bardzo szybko i bezgłośnie, więc kazałem Dajakom podążać za nim i nie tracić go z oczu, podczas gdy ja przeładowałem. Dżungla była tu pełna dużych kanciastych fragmentów skał z góry powyżej oraz gęsto porośnięta zwisającymi i splątanymi pnączami. Biegnąc, wspinając się i skradając wśród nich, dogoniliśmy stworzenie na wierzchołku wysokiego drzewa przy drodze, gdzie Chińczycy go dostrzegli, i pełnym zdziwienia głosem wykrzykiwali: „Ya Ya, Tuan; Orang-utan, Tuan”14. Widząc, że tędy nie przejdzie bez schodzenia, zawrócił ku wzgórzu, a ja oddałem dwa strzały i goniąc go, zanim znowu dotarł do ścieżki, wystrzeliłem jeszcze dwa razy, ale stale mniej lub bardziej ukrywało go listowie i chroniła wielka gałąź, po której szedł. Raz podczas przeładowywania doskonale go widziałem, poruszającego się po wielkim konarze drzewa w postawie na wpół wyprostowanej, ukazującej zwierzę olbrzymich rozmiarów. Przy ścieżce dostał się na jedno z najbardziej wyniosłych drzew w lesie i widzieliśmy, że jedna noga, złamana przez kulę, zwisa bezużytecznie. Wczepił się teraz w rozgałęzienie, w którym ukrywało go gęste listowie, i sprawiał wrażenie, że nie ma ochoty się ruszyć. Obawiałem się, że pozostanie i umrze w tej pozycji, a jako że był już prawie wieczór, nie mogłem w tym dniu kazać ściąć tego drzewa. Wypaliłem więc ponownie, a wtedy on się oddalił, choć wspinając się na wzgórze, musiał zejść na niższe drzewa. Na gałęziach jednego z nich usadowił się w takiej pozycji, że nie mógł spaść, i leżał jak kłoda, jakby martwy lub umierający.

Chciałem, żeby Dajakowie zaraz się wspięli i odcięli gałąź, na której spoczywał, ale bali się, że nie jest martwy, że ruszy i ich zaatakuje. Wobec tego trzęśliśmy przyległym drzewem, ciągnęliśmy zwisające pnącza i robiliśmy wszystko, co tylko się dało, żeby go poruszyć, ale bez skutku. Uznałem więc, że najlepiej będzie wysłać po dwóch Chińczyków z siekierami, aby ścięli to drzewo. Kiedy posłaniec odszedł, jeden z Dajaków nabrał jednak odwagi i wspiął się do niego, ale Mias, nie czekając, aż się zbliży, oddalił się na następne drzewo, gdzie wszedł na gęstą masę gałęzi i pnączy, która prawie całkiem go przed nami ukryła. $\mathrm{Na}$ szczęście drzewo było małe, więc kiedy siekiery przybyły, szybko zostało przecięte, ale z powodu lian i pnączy tak się trzymało przyległych drzew, że tylko się pochyliło. Mias się nie ruszał i zacząłem się bać, że ostatecznie go nie dopadniemy, bo wieczór był bliski, a trzeba by ściąć jeszcze pół tuzina drzew, zanim upadłoby to, na którym się znajdował. Nie mając już innych możliwości, zaczęliśmy wszyscy ciągnąc za pnącza, które mocno zatrzęsły drzewem. Po kilku minutach, kiedy już prawie straciliśmy wszelką nadzieję, zwalił się z trzaskiem i głuchym

\footnotetext{
14 Po malajsku: „Tak, tak, Panie; Orangutan, Panie”.
} 
odgłosem, jakby spadł jakiś olbrzym. A był on olbrzymem z ciałem i głową w pełni tak wielkimi jak u mężczyzny. Należał do rodzaju przez Dajaków zwanego „Mias Chappan” albo „Mias Pappan”, u którego skóra twarzy po obu stronach przechodzi w zgrubienie lub fałdę. Jego rozciągnięte ramiona mierzyły siedem stóp i trzy cale, a jego wysokość - pomiar dokładnie od czubka głowy do pięty - wynosiła cztery stopy i dwa cale. Korpus tuż pod ramionami miał trzy stopy i dwa cale obwodu i był prawie tak długi jak u mężczyzny, z nogami niezwykle krótkimi w proporcji. Przy badaniu odkryliśmy, że odniósł okropne rany. Obie nogi były złamane, jeden staw biodrowy i końcówka kręgosłupa były całkowicie strzaskane, a dwie kule znalazły się rozpłaszczone w jego szyi i szczękach! Jednak kiedy spadł, nadal żył. Dwóch Chińczyków zaniosło go przywiązanego do żerdzi do domu i cały następny dzień byliśmy z Charleyem zajęci preparowaniem skóry i gotowaniem kości, aby uzyskać doskonały szkielet — są one obecnie przechowywane w Muzeum w Derby.

Po około dziesięciu dniach, 4 czerwca, kilku Dajaków przyszło nam powiedzieć, że poprzedniego dnia jakiś Mias nieomal zabił jednego z ich towarzyszy. Kilka mil w dół rzeki stał dajacki dom i jego mieszkańcy zobaczyli przy brzegu wielkiego Oranga jedzącego młode palmowe pędy. Spłoszony wycofywał się ku pobliskiej dżungli, a kilku mężczyzn, uzbrojonych we włócznie i siekiery, wybiegło, aby mu odciąć drogę. Mężczyzna, który był z przodu, próbował przebić ciało Miasa włócznią, ale ten uchwycił ją w łapy i w jednej chwili dopadł jego ramienia. Pochwycił je pyskiem nad łokciem, zaciskając zęby na mięśniu, który rozerwał i w straszny sposób poranił ${ }^{15}$. Zupełnie bezsilny mężczyzna zostałby jeszcze poważniej zraniony, jeśli nie zabity, gdyby pozostali nie byli blisko z tyłu i wnet nie zgładzili stworzenia włóczniami i siekierami. Mężczyzna przez długi czas chorował i już nigdy w pełni nie odzyskał władzy w ręce.

Powiedzieli mi, że martwy Mias nadal leży tam, gdzie go zabito, więc zaoferowałem im zapłatę za przyniesienie go natychmiast do naszej przystani; obiecali, że to zrobią. Nie przyszli jednak aż do następnego dnia, a wtedy już zaczął się rozkład i odpadły wielkie placki włosów, więc skórowanie było bezcelowe. Bardzo żałowałem, bo był to wspaniały, w pełni wyrośnięty samiec. Odciąłem głowę i wziąłem do domu, aby ją oczyścić, podczas gdy moim ludziom kazałem zrobić wysokie na pięć stóp ogrodzenie wokół reszty ciała, które niebawem robaki, małe jaszczurki i mrówki pożrą, a mi pozostanie szkielet. Na jego twarzy było wielkie cięcie, które weszło głęboko w kość, ale czaszka była świetna, a zęby nadzwyczajnie duże i pełne.

18 czerwca odniosłem kolejny sukces i zdobyłem świetnego dorosłego samca. Pewien Chińczyk powiedział mi, że widział go żerującego obok ścieżki do rzeki i znalazłem go w tym samym miejscu, co pierwszego osobnika, którego ustrzeliłem. Posilał się okrągłym zielonym owocem z delikatną czerwoną osłoną, który podobnie jak owoc muszkatołowy zawierał gałkę. Wydawało się, że zjada tylko tę

${ }^{15}$ Scena ta została uwieczniona na frontyspisie przez Josefa Wolfa, niemieckiego ilustratora. 
gałkę, odgryzając grubą zewnętrzną łupinę, której kawałki spadały nieustannym gradem. Taki sam owoc znalazłem w żołąkach kilku innych osobników, które ustrzeliłem. Dwa strzały sprawiły, że zwierzę zwolniło uchwyt, ale wisiało jeszcze przez spory czas na jednej ręce, a potem spadło płasko na twarz i do połowy zanurzyło się w błocie. Przez kilka minut leżało, pojękując i sapiąc, podczas gdy my staliśmy dookoła, w pobliżu, spodziewając się, że każdy jego kolejny oddech będzie ostatnim. Nagle jednak uniosło się gwałtownym wysiłkiem, sprawiając, że cofnęliśmy się o jard ${ }^{16}$ albo dwa, stając prawie wyprostowane, złapało się małego drzewa i zaczęło się na nie wspinać. Następny strzał sprawił, że padło martwe. W jego języku znalazła się spłaszczona kula, która weszła w dolnej części brzucha i przeszyła całe ciało, rozłupując pierwszy kręg szyjny. Po tej straszliwej ranie uniosło się jednak jeszcze i zaczęło się wspinać ze znaczną łatwością. To także był w pełni wyrośnięty samiec, o prawie takich samych rozmiarach jak pozostałe dwa, które zmierzyłem.

21 czerwca ustrzeliłem kolejną dorosłą samicę, która na niskim drzewie jadła owoce. Była jedyną, jaką kiedykolwiek zabiłem pojedynczą kulą.

24 czerwca zostałem zawołany przez Chińczyka, żeby zabić Miasa, który, jak mówił, siedział na drzewie w pobliżu jego domu przy kopalniach węgla. Przybywszy na miejsce, mieliśmy trochę problemów ze znalezieniem zwierzęcia, bo odeszło w dżunglę, która była bardzo kamienista i trudna do przebycia. W końcu znaleźliśmy je na wysokim drzewie i zauważyłem, że jest samcem olbrzymich rozmiarów. Gdy tylko wypaliłem, ruszył wyżej i wtedy wypaliłem ponownie, a potem zobaczyliśmy, że jedno ramię ma złamane. Dotarł do najwyższej części rozległego drzewa i zaraz zaczął odłamywać wokoło gałęzie i układać je na krzyż, aby zrobić gniazdo. Ciekawie było popatrzeć, jak dobrze wybrał sobie miejsce i jak szybko wyciągał we wszystkich kierunkach niezranione ramię, odłamując z największą łatwością solidne gałęzie i układając je na krzyż, tak że w kilka minut utworzył zbitą masę listowia, która całkowicie ukryła go przed naszym wzrokiem. Najwyraźniej miał zamiar spędzić tu noc i prawdopodobnie, jeśli nie był zbyt poważnie ranny, uciekłby wcześnie następnego poranka. Dlatego ponownie wypaliłem kilka razy w nadziei, że zmuszę go do opuszczenia tego gniazda, jednak choć byłem pewien, że go trafiłem, bo po każdym strzale lekko się poruszał, nie odchodził. W końcu się uniósł, tak że połowa jego ciała stała się widoczna, a potem powoli się osunął i tylko głowa pozostała na brzegu gniazda. Byłem już pewien, że jest martwy, więc próbowałem przekonać Chińczyka i jego towarzysza, aby ścięli drzewo, ale było ono bardzo duże, a oni mieli za sobą cały dzień pracy i nic nie było w stanie ich do tego nakłonić. Następnego poranka o świcie przyszedłem na to miejsce i stwierdziłem, że Mias na pewno nie żyje, ponieważ jego głowa była widoczna w tej samej pozycji, co przedtem. Zaoferowałem czterem Chińczykom dniówki za ścięcie drzewa natychmiast, bo kilka godzin słońca

161 jard $=0,914$ metra. 
spowoduje rozkład skóry, ale popatrzyli, przymierzyli się do niego i ustalili, że jest ono bardzo duże i twarde i że nie podejmą się tego. Prawdopodobnie zaakceptowaliby moją ofertę, gdybym podwoił stawkę, bo byłaby to praca na nie dłużej niż dwie albo trzy godziny, i gdybym był tu jedynie z krótką wizytą, to tak bym zrobił. Ale ponieważ tu zamieszkałem i zamierzałem przez kilka miesięcy pozostać, byłoby błędem zacząć od przepłacania, gdyż w przyszłości niczego by dla mnie nie zrobiono po niższej stawce.

Potem przez kilka tygodni całymi dniami było widać chmurę much unoszących się nad ciałem martwego Miasa, ale po około miesiącu wszystko ucichło. Ciało, wystawione na przemian na słońce w zenicie i tropikalne deszcze, najwyraźniej wysychało. Dwa lub trzy miesiące później dwóch Malajczyków, za zaoferowanego dolara, wspięło się na drzewo i spuściło wyschnięte szczątki. Otaczająca szkielet skóra była prawie cała, lecz wewnątrz znajdowały się miliony poczwarek zamkniętych much i innych owadów, $\mathrm{z}$ tysiącami dwóch lub trzech gatunków małych padlinożernych chrząszczy. Kule mocno strzaskały czaszkę, ale szkielet był doskonały, poza małą kostką z nadgarstka, która prawdopodobnie odpadła i została zabrana przez jakąś jaszczurkę.

Trzy dni po tym, jak go ustrzeliłem i straciłem, Charles znalazł trzy małe żerujące w grupie Orangi. Długo za nimi goniliśmy i mieliśmy okazję się przyjrzeć, jak przemieszczają się z drzewa na drzewo, zawsze wybierając te konary, których gałęzie są splątane z jakimś innym drzewem, a potem chwytając razem kilka małych gałązek, zanim wykonają przeskok. Robią to jednak z taką szybkością i pewnością siebie, że przemieszczają się wśród drzew w tempie dobrych pięciu albo sześciu mil na godzinę - musieliśmy stale biec, aby za nimi nadążyć. Jednego z nich postrzeliliśmy i zabiliśmy, ale pozostał wysoko w rozgałęzieniu drzewa, a że młode zwierzęta są stosunkowo mało interesujące, nie kazałem ścinać drzewa, aby go dostać.

Przy tej okazji miałem pecha, poślizgnąłem się pomiędzy zwalonymi drzewami i zraniłem się w kostkę, a że z początku nie byłem dość ostrożny, zrobiło się ostre zapalne owrzodzenie, które nie chciało się goić, co uwięziło mnie w domu przez cały lipiec i część sierpnia. Kiedy znowu mogłem wyjść, postanowiłem wybrać się w podróż w górę odnogi rzeki Simūnjon do Semábang, gdzie był, jak mówiono, duży dajacki dom, góra obfitująca w owoce oraz mnóstwo Orangutanów i pięknych ptaków. Jako że rzeka była bardzo wąska i musiałem wyruszyć bardzo małą łódką z niewielkim bagażem, wziąłem z sobą tylko chińskiego chłopca jako służącego. Wiozłem beczułkę araku lekarskiego, aby wkładać do niego skóry Miasa, oraz zapasy i amunicję na dwa tygodnie. Po kilku milach strumień stał się bardzo wąski i kręty, a cały teren po obu stronach był zalany. Na brzegach były liczne małpy - pospolity Macacus cynomolgus, czarny Semnopithecus ${ }^{17}$ i nie-

${ }^{17}$ Hulman — małpa wąskonosa. 
zwykła małpa długonosa (Nasalis larvatus) ${ }^{18}$, która jest wielkości trzyletniego dziecka, ma bardzo długi ogon i mięsisty nos, dłuższy niż u człowieka z największym nosem. Im dalej się posuwaliśmy, tym strumień stawał się węższy i bardziej kręty; czasami zwalone drzewa blokowały nam drogę, a czasami splątane gałęzie i pnącza całkiem łączyły się w poprzek i musiały zostać wycięte, zanim mogliśmy ruszyć dalej. Dotarcie do Semábang zabrało nam dwa dni i przez całą drogę prawie nie widzieliśmy kawałka suchej ziemi. W końcowej części podróży przez całe mile mogłem dotykać krzaków po obu stronach. Często zatrzymywały nas pandany (Pandanus), które w wodzie rosły obficie i upadały w poprzek strumienia. W innych miejscach gęsta masa unoszącej się na powierzchni trawy całkowicie wypełniała koryto, czyniąc naszą podróż ciągiem nieustannych trudów.

W pobliżu przystani znaleźliśmy ładny dom, długi na dwieście pięćdziesiąt stóp, wzniesiony na palach wysoko na ziemią, z szeroką werandą i jeszcze szerszym bambusowym tarasem z przodu. Prawie wszyscy ludzie byli jednak na wyprawie po jadalne ptasie gniazda lub wosk pszczeli, a w domu pozostało jedynie dwóch albo trzech starych mężczyzn i kobiety z mnóstwem dzieci. Pobliska góra, albo górka, była całkowicie pokryta lasem owocowych drzew, wśród których obfitowały duriany ${ }^{19}$ i mangostany ${ }^{20}$, ale owoce, poza pojedynczymi sztukami, nie były jeszcze w pełni dojrzałe. Spędziłem w tym miejscu tydzień, każdego dnia wyruszając w różnych kierunkach wokół góry, w towarzystwie jednego Malajczyka, który ze mną zostawał, podczas gdy pozostali łodziarze wracali. Przez trzy dni nie znaleźliśmy żadnego Oranga, ale ustrzeliliśmy jelenia i kilka małp. Czwartego dnia trafiliśmy jednak na Miasa żerującego na wyniosłym durianie i po ośmiu strzałach udało się go zabić. Niestety pozostał na drzewie, zwisając na łapach, a my musieliśmy go zostawić i wrócić do domu, bo był oddalony o kilka mil. Byłem pewien, że w nocy spadnie, więc wcześnie rano wróciłem do tego miejsca i znalazłem go na ziemi pod drzewem. Ku memu zdziwieniu i radości okazało się, że jest innego rodzaju niż wszystkie, jakie dotąd widziałem. Choć miał w pełni rozwinięte zęby i bardzo duże kły dojrzałego samca, na twarzy nie miał ani śladu bocznych zgrubień, a wszystkie jego wymiary były o około jedną dziesiątą mniejsze niż u pozostałych dorosłych samców. Górne siekacze wydawały się jednak szersze niż u większych gatunków, co jest cechą wyróżniającą Simia morio ${ }^{21}$, opisanego na podstawie czaszki przez profesora Owena ${ }^{22}$. Jako że było zbyt daleko, aby nieść zwierzę do domu, zabrałem się do pracy i oskórowałem ciało na miejscu, zostawiając przyłączoną głowę, łapy i stopy do dokończenia w domu. Okaz ten znajduje się teraz w British Museum.

\footnotetext{
${ }^{18}$ Nosacz - małpa z rodziny koczkodanowatych.

${ }^{19}$ Zybuczkowiec - cuchnący owoc tropikalny, znany z właściwości leczniczych.

${ }^{20}$ Garcynia - smaczny, popularny owoc tropikalny.

${ }^{21}$ Podtyp orangutana.

${ }^{22}$ Sir Richard Owen (1804-1892) — angielski anatom i paleontolog.
} 
Na koniec tygodnia, nie znajdując już więcej Orangów, wróciłem do domu. Zabrawszy trochę świeżych zapasów, ruszyłem, tym razem w towarzystwie Charlesa, w górę kolejnej odnogi rzeki, o bardzo podobnym wyglądzie, do miejsca zwanego Menyille, gdzie było kilka małych dajackich domów i jeden duży. Tutaj przystanią był pomost z rozchwianych żerdzi, który obejmował znaczną połać wody. Pomyślałem, że bezpieczniej będzie zostawić moją beczułkę araku solidnie umocowaną w rozgałęzieniu drzewa. Aby zapobiec jego wypiciu przez tubylców, pozwoliłem niektórym z nich zobaczyć, jak wkładam do niego kilka węży i jaszczurek, ale sądzę, że raczej nie przeszkodziło im to w degustacji. Ulokowano nas tu na werandzie dużego domu, w którym było parę wielkich koszy z wysuszonymi ludzkimi głowami, trofeami minionych pokoleń łowców głów. Tu także była mała góra pokryta drzewami owocowymi, a przy domu rosło kilka wspaniałych durianów z dojrzałymi owocami. Dajakowie, widząc we mnie dobroczyńcę zabijającego Miasa, który mnóstwo ich owoców niszczy, pozwalali nam jeść tyle, ile mieliśmy ochotę, więc rozkoszowaliśmy się tym cesarzem owoców w jego największej doskonałości.

Następnego dnia po przybyciu do tego miejsca udało mi się ustrzelić kolejnego dorosłego samca tego mniejszego Oranga, nazywanego przez Dajaków Miasa-kassira. Nieżywy spadł, ale zahaczył o rozgałęzienie drzewa i utkwił w nim. Ponieważ bardzo pragnąłem go dostać, próbowałem namówić dwóch młodych Dajaków, którzy byli ze mną, aby ścięli drzewo. Było ono wysokie, doskonale proste, z gładką korą i pozbawione gałęzi do wysokości pięćdziesięciu albo sześćdziesięciu stóp. Ku memu zaskoczeniu powiedzieli, że wolą się wspiąć, ale będzie z tym duży kłopot. Chwilę z sobą porozmawiali, a potem powiedzieli, że spróbują. Najpierw podeszli do pobliskiej kępy bambusów i ścięli jedną z największych łodyg. Odrąbali od niej krótki kawałek i rozłupując go, zrobili parę solidnych palików, długich na około stopę i ostrych na jednym końcu. Potem, wyciąwszy gruby kawałek drewna na pobijak, wbili jeden z palików w drzewo i uwiesili się na nim. Trzymał i chyba spełniło to ich oczekiwania, bo zaczęli natychmiast robić więcej takich samych palików, podczas gdy ja przyglądałem się z wielkim zainteresowaniem, zastanawiając się, w jaki sposób mogliby wejść na takie wyniosłe drzewo, wbijając w nie jedynie paliki. Gdyby którykolwiek zawiódł na dużej wysokości, z pewnością skończyłoby się to ich śmiercią. Kiedy było zrobione około dwóch tuzinów palików, jeden z nich zaczął ścinać z kolejnej kępy bardzo długie i smukłe bambusy, a także sporządził powróz z kory małego drzewa. Następnie około trzy stopy od ziemi wbili bardzo mocno palik, przynieśli jeden z długich bambusów, postawili go prosto przy drzewie i mocno przywiązali, przy użyciu powroza z kory i małych nacięć na główce każdego palika, do pierwszych dwóch palików. Wówczas jeden z Dajaków stanął na pierwszym paliku, wbił na poziomie swojej twarzy trzeci, do którego w taki sam sposób przywiązał bambus, a potem wszedł na następny stopień, stając na jednej nodze, trzymając się bambusa przy paliku zaraz nad sobą i jednocześnie wbijając kolejny. W ten sposób wspiął się na około 
dwadzieścia stóp. Kiedy wyprostowany bambus zrobił się zbyt cienki, jego towarzysz wręczył mu kolejny, który został przyłączony przez przywiązanie obu bambusów do trzech lub czterech palików. Kiedy ten się prawie skończył, dodany został trzeci, a zaraz potem dosięgnięte zostały pierwsze gałęzie drzewa, po których młody Dajak się wdrapał i wkrótce zwalił Miasa głową w dół. Byłem pod niezmiernym wrażeniem pomysłowości takiej metody wspinania się i zachwycającego sposobu, w jaki zostały wykorzystane szczególne właściwości bambusa. Drabina była absolutnie bezpieczna, bo gdyby którykolwiek z palików poluzował się lub był wadliwy i się ugiął, ciężar zostałby przerzucony na kilka innych, niżej i wyżej. Wtedy zrozumiałem zastosowanie tkwiących w drzewach rzędów bambusowych palików, które często widziałem i zastanawiałem się, w jakim celu mogły zostać tam umieszczone. Zwierzę było prawie identycznych rozmiarów i wyglądu jak to, które zdobyłem w Semábang, i było drugim, a zarazem ostatnim okazem Simia morio, jaki napotkałem. Teraz znajduje się w Derby Museum.

Później ustrzeliłem dwie dorosłe samice i dwa młode w różnym wieku; wszystkie osobniki zakonserwowałem. Jedna $\mathrm{z}$ tych samic posilała się z kilkoma młodszymi na durianie z niedojrzałymi owocami. Gdy tylko nas zobaczyła, zaczęła z absolutną wściekłością odłamywać gałęzie i wielkie kolczaste owoce, wywołując taki deszcz pocisków, że skutecznie uniemożliwiała nam podejście zbyt blisko drzewa. Powątpiewano w ten zwyczaj zrzucania w gniewie gałęzi, ale - tak jak tu opowiedziano - sam go zaobserwowałem przy co najmniej trzech osobnych okazjach. Zawsze to jednak samica Miasa zachowywała się w ten sposób. Możliwe, że samiec, bardziej ufając swej wielkiej sile i potężnym kłom, nie boi się żadnych zwierząt i nie chce ich odganiać, podczas gdy instynkt rodzicielski popycha samicę do stosowania tej metody obrony siebie i młodych.

Podczas preparowania skór i szkieletów tych zwierząt bardzo mnie niepokoiły dajackie psy, które zawsze są na wpół zagłodzone i zabijają się o mięso zwierzęce. Miałem wielki żelazny garnek, w którym gotowałem kości, aby uzyskać szkielety. W nocy nakrywałem go deskami i kładłem na nim ciężkie kamienie, ale psy zdołały je zdjąć i porwały większą część jednego z okazów. Przy innej okazji odgryzły sporo górnej części skóry z moich solidnych butów, a nawet zjadły kawałek mojej moskitiery, na który kilka tygodni wcześniej rozlało się trochę oleju do lampy.

Podczas powrotu w dół strumienia szczęśliwym trafem natknęliśmy się na bardzo starego samca Miasa żerującego na niskich drzewach rosnących w wodzie. Teren był szeroko zalany, ale tak pełen drzew i pniaków, że załadowanej łodzi nie dawało się między nie wepchnąć, a nawet gdyby się dało, to i tak tylko spłoszylibyśmy tego Miasa. Wszedłem więc do wody, która sięgała mi prawie do pasa, i brnąłem, aż znalazłem się wystarczająco blisko, aby oddać strzał. Potem był problem z ponownym załadowaniem, bo byłem tak głęboko w wodzie, że nie mogłem utrzymać broni wystarczająco pochylonej, aby nasypać prochu, przez co musiałem szukać jakiegoś płytkiego miejsca. Po kilku strzałach w tych trud- 
nych warunkach byłem więc uradowany, widząc, jak ten monstrualny zwierzak przewraca się do wody. Przyciągnąłem go za sobą do strumienia, ale Malajczycy sprzeciwili się ładowaniu zwierzaka do łodzi, a był on tak ciężki, że nie zrobiłbym tego bez ich pomocy. Rozejrzałem się za miejscem do oskórowania go, ale nie było widać ani kawałka suchego gruntu. W końcu znalazłem kępę dwóch czy trzech starych drzew i pniaków, między którymi zebrało się tuż ponad wodą kilka stóp ziemi - akurat tyle, żebyśmy zwierzaka na nią wciągnęli. Najpierw go zmierzyłem i odkryłem, że zdecydowanie jest największym, jakiego dotąd widziałem, bo choć wysokość w pozycji stojącej była taka sama jak u pozostałych (cztery stopy i dwa cale), to jednak rozciągnięte ramiona miały siedem stóp i dziewięć cali, czyli sześć cali więcej niż u poprzedniego, a ogromna twarz miała trzynaście i pół cala szerokości, podczas gdy najszersza, jaką dotychczas widziałem, miała tylko jedenaście i pół cala. Obwód ciała wynosił trzy stopy i siedem i pół cala. Jestem więc skłonny wierzyć, że długość i siła ramion oraz szerokość twarzy stale wzrasta, aż do bardzo późnego wieku, podczas gdy wysokość w pozycji stojącej, od podeszwy stopy do czubka głowy, rzadko, jeśli w ogóle, przekracza cztery stopy i dwa cale.

[...] był to ostatni Mias, jakiego ustrzeliłem, i ostatni raz, kiedy widziałem dorosłe, żywe zwierzę [...].

\section{Celebes - Menado ${ }^{23}$}

Tuż naprzeciw mojej siedziby w Rurúkan ${ }^{24}$ znajdował się budynek szkoły, której dyrektorem był tubylec, wykształcony przez misjonarzy w Tomohón ${ }^{25}$. Lekcje odbywały się każdego poranka przez około trzy godziny, a dwa razy w tygodniu, wieczorami, była katecheza i kazania. W niedzielne poranki odprawiano także nabożeństwo. Dzieci uczono po malajsku i często słyszałem, jak powtarzały bez zająknięcia tabliczkę mnożenia aż do dwadzieścia razy dwadzieścia. Zawsze kończyły śpiewem i było bardzo przyjemnie posłuchać w tych odległych górach wielu starych melodii naszych psalmów, śpiewanych z malajskimi słowami. Śpiewanie jest jednym z prawdziwych błogosławieństw wprowadzanych przez misjonarzy wśród dzikich narodów, których tubylcze pieśni są zawsze monotonne i melancholijne.

W wieczory katechetyczne dyrektor szkoły był ważną osobą. Wygłaszał kazania i nauczał przez trzy godziny jednym ciągiem, zupełnie w stylu angielskiego deklamatora. Było to zajęcie dość obojętne jego słuchaczom, ale dla niego samego pobudzające. Skłaniam się ku przekonaniu, że ci tubylczy nauczyciele,

\footnotetext{
${ }^{23}$ Manado - miasto na północy wyspy Celebes, stolica prowincji Celebes Północny.

24 Wioska na południowy wschód od Manado.

${ }^{25}$ Wioska w pobliżu Rurúkan.
} 
zyskawszy łatwość przemawiania i nieskończone zasoby religijnych frazesów, uprawiają swoje hobby całkiem bez umiaru, niewiele zwracając uwagi na swoją trzódkę. W tym kraju misjonarze mogą jednak być dumni z wielu rzeczy. Pomogli rządowi zmienić dzikusów w cywilizowaną wspólnotę w zdumiewająco krótkim czasie. Czterdzieści lat temu kraj ten był dziczą, a ludzie nagimi dzikusami ozdabiającymi swe prymitywne domy ludzkimi głowami. Teraz jest to ogród wart swojej uroczej tubylczej nazwy „Minahasa” ${ }^{26}$. Dobre drogi i ścieżki biegną w każdym kierunku, jedne z najwspanialszych na świecie plantacji kawy otaczają wioski usiane rozległymi polami ryżowymi, które w nadmiarze zaspokajają potrzeby ludności.

Tutejsi ludzie są obecnie najbardziej pracowici, pokojowi i cywilizowani na całym półwyspie. Są najlepiej ubrani, mają najlepsze domy, są najlepiej odżywieni i najlepiej wykształceni i dokonali pewnego postępu ku wyższemu stanowi społecznemu. Sądzę, że nie ma nigdzie indziej żadnego przykładu tak zdumiewających rezultatów osiągniętych w tak krótkim czasie - rezultatów, których wyłączną przyczyną jest system sprawowania władzy obecnie przyjęty przez Holendrów w ich wschodnich posiadłościach. Jest to taki system, który można by nazwać „paternalnym despotyzmem”. My, Anglicy, nie lubimy despotyzmu nienawidzimy tej nazwy i rzeczy. Wolimy uważać ludzi za ciemnych, leniwych i złych, byle nie użyć innej niż duchowa siły, aby uczynić ich mądrymi, pracowitymi i dobrymi. I jest to słuszne, kiedy mamy do czynienia z ludźmi naszej rasy, o podobnych poglądach i ze zdolnościami równymi naszym. Przykład i nauka, siła opinii publicznej i powolne, ale niezawodne szerzenie edukacji z czasem dokonają wszystkiego, nie wywołując żadnego rozgoryczenia ani nie doprowadzając do jakiejś służalczości, hipokryzji i zależności, które niewątpliwie są skutkami despotycznych rządów. Ale co pomyśleć o człowieku, który opowiadałby się za takimi zasadami pełnej wolności w rodzinie lub szkole? Powinniśmy powiedzieć, że przykłada dobrą ogólną zasadę do przypadku, w którym warunki czynią ją niestosowalną — do przypadku, w którym rządzeni są w stanie udowodnionej niższości umysłowej w stosunku do tych, którzy nimi rządzą, i nie potrafią decydować, co jest najlepsze dla ich trwałego dobra. Dzieci muszą być do pewnego stopnia poddane władzy i przewodnictwu, a jeśli będą właściwie pokierowane, to chętnie ulegną, ponieważ wiedzą o swojej niższości i wierzą, że starsi działają wyłącznie dla ich dobra. Uczą się wielu rzeczy, których zastosowania nie pojmują i których nigdy nie nauczyłyby się bez pewnej moralnej i społecznej, jeśli nie fizycznej, presji. Nawyk utrzymywania porządku, pracowitości, czystości, szacunku i posłuszeństwa wpaja się podobnymi środkami. Dzieci nigdy nie wyrosłyby na dobrze wychowanych i dobrze wykształconych ludzi, gdyby im pozwolono na taką samą nieograniczoną wolność działania, jaka dozwolona jest dorosłym. Najlepsza edukacja polega na tym, że dzieci są poddawane łagodnemu despotyzmowi dla

${ }^{26}$ W języku Tombulu — 'zjednoczeni'. 
dobra ich samych i społeczeństwa, a ich ufność w mądrość i dobroć tych, którzy stanowią i stosują ten despotyzm, neutralizuje złe namiętności i hańbiące uczucia, które w mniej sprzyjających warunkach są jego powszechnymi skutkami.

Tu nie ma jedynie analogii — pod wieloma względami istnieje tożsamość relacji między z jednej strony mistrzem a uczniem lub dzieckiem a rodzicem i z drugiej strony między niecywilizowaną rasą a jej władcami. Wiemy (lub sądzimy, że wiemy), że wykształcenie i pracowitość oraz powszechne zwyczaje cywilizowanego człowieka przewyższają życie dzikie, a dzikus, poznawszy je, sam to przyznaje. Podziwia wyższe umiejętności człowieka cywilizowanego i z dumą wręcz przyswaja sobie te zwyczaje, które zbytnio nie kolidują z jego gnuśnością, namiętnościami lub przesądami. Ale tak jak uparte dziecko lub próżnujący uczeń, którego nigdy nie nauczono posłuszeństwa i nigdy nie zmuszono do zrobienia niczego, czego z własnej woli nie jest skłonny zrobić, w większości wypadków ani nie zdobędzie wykształcenia, ani nie nabierze manier, tak samo bardziej jest prawdopodobne, że dzikus, z tymi wszystkimi utrwalonymi nawykami wieku dojrzałego i tradycyjnymi plemiennymi przesądami, bez bodźca silniejszego niż pouczenie, niedostatecznie wsparte przykładem, nie zrobi niczego poza skopiowaniem kilku z najmniej pożytecznych zwyczajów cywilizacji.

Jeśli jesteśmy przekonani, że słusznie obejmujemy rządy nad dziką rasą i okupujemy jej kraj, oraz jeśli ponadto uważamy za swój obowiązek robić wszystko, co tylko możliwe, aby doskonalić naszych prymitywnych poddanych i podnosić ich do naszego własnego poziomu, nie wolno nam nadmiernie się obawiać wrzawy wokół „despotyzmu” lub „niewolnictwa”. Musimy wykorzystać posiadaną władzę, aby ich nakłonić do wykonywania pracy, której mogą w ogóle nie lubić, ale która, jak wiemy, jest niezbędnym krokiem ku ich moralnemu i materialnemu rozwojowi. Holendrzy, robiąc to, wykazali się bardzo dobrą taktyką. W większości przypadków utrzymali i umocnili władzę tubylczych wodzów, którym ludzie zwykli okazywać dobrowolne posłuszeństwo. Postępując zaś zgodnie z rozeznaniem i interesem własnym wodzów, wprowadzili w postawach i zwyczajach tych ludzi zmiany, które spowodowałyby urazy i być może bunt, gdyby zostały narzucone bezpośrednio przez obcokrajowców.

Przy wprowadzaniu takiego systemu dużo zależy od charakteru ludu, a system, który przynosi godne podziwu sukcesy w jednym miejscu, w innym może zadziałać jedynie częściowo. W Minahasie naturalna uległość i inteligencja rasy sprawiły, że jej postęp był szybki. Wagę tego dobrze ilustruje to, że w bezpośrednim sąsiedztwie miasta Menado jest plemię zwane Bantekami, o dużo mniej łagodnym usposobieniu. Jak dotąd stawiają oni opór wszelkim wysiłkom Rządu Holenderskiego mającym nakłonić ich do jakiejkolwiek systematycznej uprawy ziemi. Pozostają w stanie bardziej prymitywnym, ale chętnie się zatrudniają dorywczo jako tragarze i robotnicy, do czego są dobrze przystosowani ze względu na dużą siłę i energię. 
Bez wątpienia przedstawiony tu $\mathrm{w}$ zarysie system może dawać powody do poważnych zarzutów. Do pewnego stopnia jest despotyczny i koliduje z wolnym handlem, wolnością pracowniczą i wolną komunikacją. Tubylec nie może opuścić wioski bez przepustki i nie może bez zgody Rządu zatrudnić się u żadnego kupca czy wodza. Cała kawa musi być sprzedawana Rządowi za mniej niż połowę ceny, którą dałby lokalny kupiec, i w związku z tym oburza się on głośno na „monopol” i ,ucisk”. Zapomina jednak, że plantacje kawy zostały założone przez Rząd przy wielkim nakładzie kapitału i umiejętności, że daje on ludziom bezpłatną edukację i że monopol zastępuje podatki. Zapomina, że produkt, który chce nabyć i na którym chce zyskać, został stworzony przez Rząd, bez którego ci ludzie nadal byliby dzikusami. Wie bardzo dobrze, że wolny handel w pierwszym rzędzie doprowadziłby do importu całych ładunków araku, który byłby rozprowadzany po kraju i wymieniany na kawę. Że w kraju rozpowszechniłoby się pijaństwo i ubóstwo, że nie utrzymywano by państwowych plantacji kawy, że wkrótce spadłaby jakość i ilość kawy, że handlarze i kupcy wzbogaciliby się, ale ludzie z powrotem popadliby w ubóstwo i barbarzyństwo. Że nieodmiennie taki jest rezultat wolnego handlu z jakimikolwiek dzikimi plemionami, które posiadają jakiś cenny produkt, rodzimy lub uprawiany, dobrze jest wiadome tym, którzy odwiedzali takich ludzi, ale nawet z zasad ogólnych możemy wywnioskować, że źle by się to skończyło. Jeśli wielkie prawo ciągłości lub rozwoju ma mieć zastosowanie bardziej do czegokolwiek niż do czegoś innego, to właśnie do ludzkiego postępu. Są pewne etapy, przez które społeczeństwo musi przejść w swym marszu od barbarzyństwa ku cywilizacji. Jednym z tych etapów właściwie zawsze była jakaś forma despotyzmu, jak feudalizm lub niewola, albo rządy paternalnego despotyzmu. Mamy wszelkie powody, aby uważać, że ludzkość nie jest w stanie przeskoczyć tej przejściowej epoki i przejść od razu od czystej dzikości do wolnej cywilizacji. System holenderski jest próbą uzupełnienia tego brakującego ogniwa i stopniowego doprowadzenia ludzi do tej wyższej cywilizacji, którą my (Anglicy) chcemy im natychmiast narzucić. Nasz system za każdym razem ponosił klęskę. Demoralizujemy i tępimy, ale nigdy tak naprawdę nie cywilizujemy. Nie jest pewne, czy system holenderski odniesie trwały sukces, ponieważ skupienie dzieła dziesięciu stuleci w jednym może być niewykonalne, ale w każdym razie naśladuje on naturę i dlatego bardziej zasługuje na sukces i ma na niego większą szansę niż nasz.

$Z$ tą kwestią związana jest jeszcze jedna sprawa, którą, jak uważam, mogliby podjać misjonarze, uzyskując przy tym wspaniałe materialne i moralne rezultaty. W tym pięknym i zdrowym kraju, z obfitością żywności i tego, co niezbędne, populacja nie wzrasta tak jak powinna. Przypisać to mogę tylko jednej przyczynie - śmiertelności niemowląt spowodowanej ich zaniedbaniem, kiedy matki pracują na plantacjach, oraz powszechną nieznajomością uwarunkowań zdrowia niemowląt. Wszystkie kobiety pracują, tak jak od zawsze były do tego przyzwyczajone. Nie jest to dla nich żaden trud, lecz często, jak uważam, przyjemność i relaks. Albo biorą niemowlęta z sobą, a w takim wypadku zostawiają je na ziemi 
w jakimś zacienionym miejscu i co jakiś czas przychodzą je karmić, albo zostawiają je w domu pod opieką innych dzieci, które są zbyt młode, aby pracować. W żadnej z tych sytuacji niemowlęta nie są dostatecznie zadbane. Rezultatem jest wysoka śmiertelność, która utrzymuje wzrost populacji dalece poniżej poziomu, jakiego moglibyśmy oczekiwać na podstawie ogólnego krajowego dobrobytu i powszechności ślubów. Jest to sprawa, którą Rząd jest bezpośrednio zainteresowany, ponieważ sam wzrost populacji może skutkować dużym i trwałym wzrostem produkcji kawy. Misjonarze powinni podjąć tę kwestię, ponieważ nakłaniając zamężne kobiety do ograniczenia się do obowiązków domowych, zdecydowanie będą promować wyższą cywilizację oraz bezpośrednio zwiększać zdrowotność i szczęście całej wspólnoty. Ci ludzie są tak potulni i skłonni do przyjęcia manier i zwyczajów Europejczyków, że z łatwością można tę zmianę wprowadzić, pokazując im jedynie, że jest ona kwestią moralności i cywilizacji oraz istotnym krokiem w postępie ku równości z białymi władcami.

Z języka angielskiego przełożyt

Krzysztof Tańczuk 